\title{
The difficulties of the elementary school students in solving the mathematical narrative-type test items
}

\author{
Dwi Widyastuti Nurharyanto*, Heri Retnawati \\ Universitas Negeri Yogyakarta. Jalan Colombo No. 1, Yogyakarya 55281, Indonesia \\ *Corresponding Author: E-mail: dwiwidyastuti.2018@student.uny.ac.id
}

Received: 3 February 2020; Revised: 9 March 2020; Accepted: 27 April 2020

\begin{abstract}
Mathematical learning is based on the contexts within the daily life activities and is reflected in the evaluative test items that have been administered to the students. One of the appropriate test items that might be administered by the teachers is the narrative-type test items. The narrative-type test items is more difficult than the other type of test items because this type of test item does not directly display the mathematical model but, instead, displays the narration that the students should understand first. With reference to the statement, the present study has adopted the phenomenological approach in order to identify the difficulties that the students might encounter in solving the mathematical problems that have been presented in the narrative-type test items. Within the conduct of the study, 121 students from Grade $\mathrm{V}$ of five selected elementary schools in the Province of Yogyakarta Special Region had been involved as the participants. During the analysis, the students' errors that had been found were analysed by using the Newman Model data analysis method. According to the model, the students' errors should be grouped into five categories namely: (1) reading; (2) comprehension; (3) process; (4) skill; and (5) encoding. The results of the study show that in general the students do not experience any difficulty in the reading of context of the test items but $44.04 \%$ of the students have difficulties in the understanding toward the context of the test items (comprehension), $40.22 \%$ of the students have difficulties in transformation, $57.44 \%$ of the students have difficulties in process skills, and $57.44 \%$ of the students have difficulties in the encoding as well. Then, most of the errors have been found in the problem number 3 and the type of the errors is the reading errors. One of the causes behind such finding is that the students' semantic skills have not been in-depth yet. Consequently, the students might commit errors in the subsequent stages.
\end{abstract}

Keywords: students' difficulties, phenomenology, narrative-type test items, Newman Analysis Method

How to Cite: Nurharyanto, D., \& Retnawati, H. (2020). The difficulties of the elementary school students in solving the mathematical narrative test items. Jurnal Prima Edukasia, 8(1), 29-39. doi:https://doi.org/10.21831/jpe.v8i1.29969

\section{Introduction}

Mathematics is one of the lessons that have been taught in all education degrees throughout Indonesia. Recently, Mathematics has put more emphasis on the problem-solving process (Charlesworth \& Lind, 2010, p. 212; Pugalee, 2001). As a result, the students' skills in Mathematics are measured by looking at the students' capacity in solving the given problems. Thus, the problem-solving skills become important because these skills serve as the foundation for the students in completing all learning stages. However, the problem-solving skills in Mathematics might be more difficult than the arithmetic skills themselves (Tong \& Loc, 2017, p. 226). If the students are unable to solve the problems, then it will be daunting for the students to start performing the numeric operation within the given test items. Certainly, this aspect is also directly related to how the test items are administered to the students.

The presentation of the problems for the students should be in accordance to the students' daily life. In relation to the statement, the most appropriate type of test items for this context is the narrativetype test items (Newton, 2017, p. 88). Narrative-type test items belong to the subjective test item category. Different than the objective test item category in which the students might define the answers by means of guessing, the narrative-type test items are difficult to complete because these test items require an elaboration toward the process of the answer finding (Rahmawati \& Retnawati, 2019). At the 
elementary school degree, the narrative-type test item might facilitate the students to understand the problems and thus to solve the given problems.

Nowadays, the use of narrative-type test item has been frequently implemented in the students' worksheets. However, there is one step that has always been forgotten namely the preliminary step which aims at identifying the students' difficulties in solving the problems. The difficulties might come from either the test item materials or the test item type that has been adopted. Prior to the students' test administration, there should be pre-test activities in order to identify how far the students have been dealing with the difficulties. The statement also applies to the learning process which delivers the narrative-type test item as part of learning evaluation. The intention of applying the narrative-type test item is that the learning process that has been taking place might overcome the students' difficulties that have been identified so that the errors might be minimized during the final test administration. Unfortunately, this initiative has rarely been done and usually it has just been skipped.

The narrative-type test item has put higher priority on the students' processing and procedural skills. This is the competitive edge of the narrative-type test item that sometimes has not been utilized due to the inappropriate implementation among the students. The students always encounter the same difficulty, namely that they have been unable to arrive at the final stage of the process elaboration (Jiang, 2013, p. 68). In their study, Wijaya et al. (2014, p. 579) and also Sumantri and Satriani (2016, p. 517) have found that the narrative-type test item is easier to be completed by the students who have highlevel cognitive skills. On the contrary, the students with low-level cognitive skills tend to favour the multiple choice-type test item.

The difficulties in the process of administering the narrative-type test item has not only been experienced by the elementary school-degree students but also the high school-degree students. In this regard, numerous studies have been conducted to the junior high school students and the senior high school students (Abdullah et al., 2015, pp. 133-142; Hadi et al., 2018, pp. 520-532; Retnawati, 2017, pp. 33-50). The results of these studies concurrently display that the high school-degree students still suffer from difficulties within the narrative-type test item administration. Certainly, it becomes the basis that the elementary school-degree students possible suffer from the similar difficulties or even harder difficulties in comparison to the students from the higher degree.

Why is the narrative-type test item so difficult to administer? One of the reasons might be that the lack of information that has been attained in the reading activities becomes the error that has been mostly committed. Loss of information has caused several data that should serve as the means for finding the answer into absence and has eventually led into an error in delivering the answer (Ulu, 2017, p. 562). On the other hand, the loss of information might have also been caused by the narrative-type test item that does not directly present the substance but, instead, that pays attention more on the details of the narration.

The presentation of the narrative-type test item should be similar or should at least be closer to the situations that really take place in the students' life. The reason is that the students prefer the narrative-type test item that directs them more to the mathematical substance rather than the details of the narration (Große, 2014, p. 631). The details that are too specific within a narrative-type test item sometimes do not facilitate the students in identifying the appropriate strategy but, instead, do make the students confused in understanding the given context. Another factor that might be influential for the students as well in this case is the inaccuracy of the students in identifying the strategy that should be implemented and the unwillingness to re-check the answers that have been found (Arfiana \& Wijaya, 2018, p. 220).

Based on the theories that have been reviewed, most of the studies that have been conducted deal with the high school-degree students. Certainly, there are differences between the elementary schooldegree students and the high school-degree (junior/senior high school) students both in terms of materials and in terms of characteristics. Therefore, the present study is conducted in order to provide explanations on the difficulties that the elementary school students have been dealing with. Then, the results that have been gathered from the data collection process will be analysed by using the Newman Analysis Model. 
Jurnal Prima Edukasia, 8 (1), 2020 - 31

Dwi Widyastuti Nurharyanto, Heri Retnawati

\begin{abstract}
Method
The study was a phenomenological research which aimed at identifying the students' difficulties in solving the mathematical problems that had been presented in the form of narrative-type test item. The students' difficulties were analysed based on the Newman Analysis Model. The Newman Analysis Model consists of five error stages namely: (1) reading error (the error in reading the narrative-type test item); (2) comprehension error (the error in comprehending the narrative-type test item or the problems presented in the narrative-type test item); (3) transformation error (the error in formulating the mathematical model); (4) process-skills error (the error in implementing the process skills); and (5) encoding error (the error in formulating the final answer). The indicators for the Newman Analysis Method might be consulted in Table 1 .
\end{abstract}

Table 1. Indicators of Newman Analysis Model

\begin{tabular}{|c|c|c|}
\hline No. & $\begin{array}{c}\text { Newman Analysis } \\
\text { Method }\end{array}$ & Indicator \\
\hline 1. & Reading & Students are able to read the test items. \\
\hline 2. & Comprehension & $\begin{array}{l}\text { Students are able to comprehend the given problems and identify the } \\
\text { important information. }\end{array}$ \\
\hline 3. & Transformation & $\begin{array}{l}\text { Students are able to transform the given problems into the mathematical } \\
\text { models. }\end{array}$ \\
\hline 4. & Process Skill & $\begin{array}{l}\text { Students are able to solve the problems that have been processed into the } \\
\text { mathematical models. }\end{array}$ \\
\hline 5. & Encoding & Students are able to encode the final results of the calculation process. \\
\hline
\end{tabular}

Within the conduct of the study, 121 students had been elected as the participants. The 121 students were Grade V students from five schools namely: (1) First State Elementary School Madusari; (2) Third State Elementary School Madusari; (3) Second State Elementary School Potrojayan; (4) Third State Elementary School Potrojayan; and (5) Canisius Elementary School. All of these schools were located in Totogan, District of Prambanan, Regency of Sleman, Province of Yogyakarta Special Region. Then, the 121 Grade V students in the study consisted of 45 male students and 75 female students with heterogeneous level of academic capacity (low, moderate, and high). These participants were assumed to have already attended the learning process of Fraction Numeric Operation materials, which had been administered in the research instrument.

The study was conducted in November 2019 by using test administration technique in order to identify how far the students had understood the learning materials. The students were provided with 6 narrative-type test items which consisted of fraction numeric operation that had been delivered in the learning of Grade V Semester I. With regards to the test administration, the validity construct had been attained by means of expert judgment and had been tested to 30 students outside the participants prior to the conduct of the study. The results of the validity test showed that the 6 narrative-type test items had been valid and therefore might be implemented as the research instrument. On the other hand, the reliability of the narrative-type test item had been measured by using the Alpha Cronbach Coefficient. The result of the reliability test showed that the 6 narrative-type test item belonged to the "High" category $(0.833)$.

The narrative-type test items were administered to the students and the results that had been gathered from the narrative-type test item administration were analysed in order to identify the errors that had been committed and the results of the error analysis described the difficulties that the students had experienced during the test administration. The students should administer the narrative-type test items as part of their preparation for the conduct of the final semester examination. Consequently, the results from the test administration might be accurate since the students completed the test items just like usual in the learning process. However, in order to maintain the objectivity within the conduct of the study, the identify of the students should be kept in secrecy and the results of the study did not influence the both the students' achievement and the elementary schools' achievement.

The data that had been gathered were analysed in accordance to the indicators of the Newman Analysis Method by using the five error stages that had been previously elaborated. The errors that the students had committed in the preliminary stage might influence the students' performance in the 
Jurnal Prima Edukasia, 8 (1), 2020 - 32

Dwi Widyastuti Nurharyanto, Heri Retnawati

subsequent stage. As a result, in one narrative-type test item the students might commit more than one errors.

\section{Results and Discussion}

Result

The Newman Analysis Method categorized the students' answers into five types of errors. These five types of errors consisted of reading errors, comprehension errors, transformation errors, processskill errors, and encoding errors. In addition to the five types of errors, there were two other alternatives namely correct answer and non-responded test item.

The results of the analysis toward the students' errors in completing the narrative-type test item might be consulted in the following tables.

Table 2. Problem Number 1

\begin{tabular}{clccc}
\hline No. & & Type of Error & $\mathrm{N}$ & $\%$ \\
\hline 1. & Correct Answer & 46 & 38.02 \\
2. & Non-Responded Test Item & 0 & 0 \\
3. & Reading & 0 & 0 \\
4. & Comprehension & 26 & 21.29 \\
5. & Transformation & 31 & 25.62 \\
6. & Process Skill & 66 & 54.55 \\
7. & Encoding & 65 & 53.72 \\
\hline
\end{tabular}

The students mostly committed errors in the process-skill and the error percentage was $54.55 \%$. However, there were several students who had correctly responded to the narrative-type test item (Table 2).

Table 3. Problem Number 2

\begin{tabular}{clccc}
\hline No. & & Type of Error & N & $\%$ \\
\hline 1. & Correct Answer & 57 & 47.1 \\
2. & Non-Responded Test Item & 1 & 0.83 \\
3. & Reading & 1 & 0.83 \\
4. & Comprehension & 27 & 22.3 \\
5. & Transformation & 28 & 23.1 \\
6. & Process Skill & 73 & 60.3 \\
7. & Encoding & 75 & 62.0 \\
\hline
\end{tabular}

The problem number 2 was quite difficult from the perspective of encoding errors (Table 3 ). As a result, more than half of the students committed errors in the process of finding the answer.

Table 4. Problem Number 3

\begin{tabular}{clccc}
\hline No. & & Type of Error & $\mathrm{N}$ & $\%$ \\
\hline 1. & Correct Answer & 1 & 0.83 \\
2. & Non-Responded Test Item & 7 & 5.79 \\
3. & Reading & 1 & 0.83 \\
4. & Comprehension & 113 & 93.39 \\
5. & Transformation & 44 & 36.36 \\
6. & Process Skill & 53 & 43.8 \\
7. & Encoding & 52 & 42.98 \\
\hline
\end{tabular}

From the data in Table 4, it was found that errors that the students had mostly committed the comprehension errors. The students had difficulties in understanding the context of the test-item. As a result, they also commit errors in the subsequent stages. In this case, there was only one student who has responded correctly to the narrative-type test item.

Table 5 displays the results of data analysis from the problems in Number 4. From the data in Table 5, it is apparent that the students mostly commit the encoding error. Specifically, more than 50\% of the participants committed the errors in this stage. 
Jurnal Prima Edukasia, 8 (1), 2020 - 33

Dwi Widyastuti Nurharyanto, Heri Retnawati

Table 5. Problem Number 4

\begin{tabular}{clccc}
\hline No. & & Type of Error & $\mathrm{N}$ & $\%$ \\
\hline 1. & Correct Answer & 37 & 30.58 \\
2. & Non-Responded Test Item & 7 & 5.79 \\
3. & Reading & 0 & 0 \\
4. & Comprehension & 28 & 23.14 \\
5. & Transformation & 37 & 30.58 \\
6. & Process Skill & 54 & 44.63 \\
7. & Encoding & 67 & 55.37 \\
\hline
\end{tabular}

The cause behind the students' encoding error (Table 5) might be traced back into the previous stage namely comprehension, transformation, and process skill. This finding confirmed that the error that the students had committed in the preliminary stage might influence their performance in the subsequent stages.

Table 6. Problem Number 5

\begin{tabular}{clccc}
\hline No. & & Type of Error & $\mathrm{N}$ & $\%$ \\
\hline 1. & Correct Answer & 4 & 3.31 \\
2. & Non-Responded Test Item & 14 & 11.57 \\
3. & Reading & 0 & 0 \\
4. & Comprehension & 26 & 21.49 \\
5. & Transformation & 98 & 80.99 \\
6. & Process Skill & 100 & 82.64 \\
7. & Encoding & 89 & 73.55 \\
\hline
\end{tabular}

Table 6 displays that the students committed errors in the transformation, process-skill, and encoding. In this case, most of the students were able to understand the given problems and yet they were caught in the subsequent stage.

Table 7. Problem Number 6

\begin{tabular}{|c|c|c|c|}
\hline No. & Type of Error & $\mathrm{N}$ & $\%$ \\
\hline 1. & Correct Answer & 1 & 0.83 \\
\hline 2. & Non-Responded Test Item & 18 & 14.88 \\
\hline 3. & Reading & 0 & 0 \\
\hline 4. & Comprehension & 100 & 82.64 \\
\hline 5. & Transformation & 55 & 45.45 \\
\hline 6. & Process Skill & 71 & 58.68 \\
\hline 7. & Encoding & 69 & 57.02 \\
\hline
\end{tabular}

The data in Table 7 also provide one of the difficulties that the students had encountered since there had only been one student who responded correctly to the narrative-type test item. In this case, the error that the students mostly committed was comprehension. The Problem Number 6 was quite similar to the Problem Number 3 . Since the error had taken place in preliminary stage, the subsequent stage was influenced.

Table 8. Mean Score Percentage

\begin{tabular}{|c|c|c|}
\hline No. & Type of Error & $\%$ \\
\hline 1. & Correct Answer & 20.11 \\
\hline 2. & Non-Responded Test Item & 6.48 \\
\hline 3. & Reading & 0.28 \\
\hline 4. & Comprehension & 44.04 \\
\hline 5. & Transformation & 40.36 \\
\hline 6. & Process Skill & 57.44 \\
\hline 7. & Encoding & 57.44 \\
\hline
\end{tabular}

The data in Table 8 inform that the students still had difficulties in administering the narrativetype test item. The data had been confirmed by the low percentage of the students who had responded appropriately to the narrative-type test item (mean percentage 20.11\%). Then, Problem Number 3 had been the most difficult one because there was only one student who had correctly responded to the 
narrative-type test item with the percentage $0.83 \%$. Indeed, all problems had been solved; however, the answers that had been found were incomplete. Departing from the above tables, it might be indicated that the students had difficulties in solving the problems that had been administered in the form of narrative-type test item. The graphic of the students' difficulties might be consulted in Figure 1.

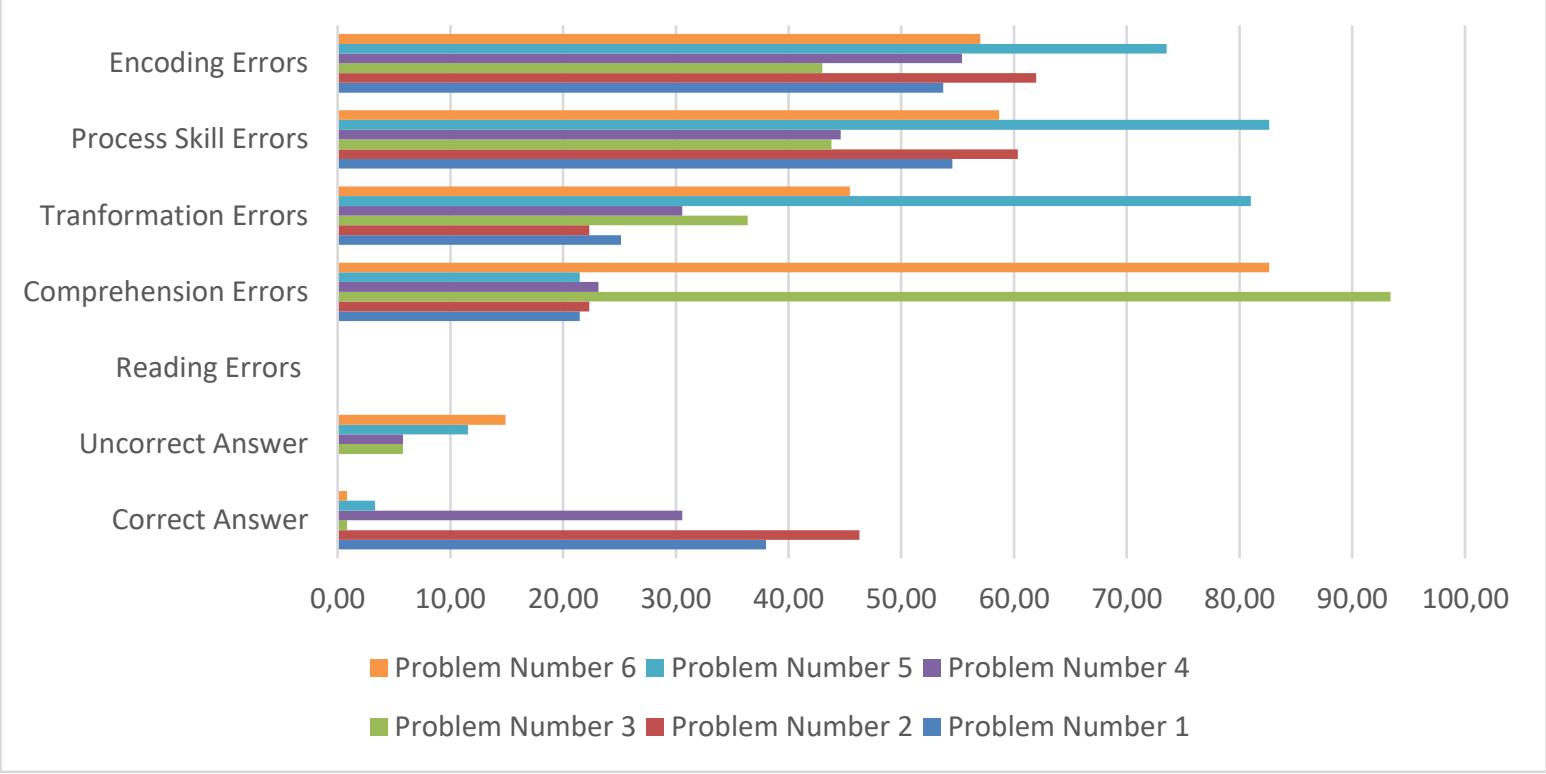

Figure 1. Graphic of Students' Difficulties in Administering the Narrative-Type Test Item

Most of the students responded correctly to the Problem Number 2. This finding shows that the Problem Number 2 had been the most understandable and the easiest problem to solve among the students. The Problem Number 2 provided clear information so that it might be easy for the students to understand the problem in order to define the problem-solving steps. However, the students still suffered from certain difficulties and one of these difficulties was that the information contained in the Problem Number 2 had been provided in the implicit form instead of explicit form; consequently, it was difficult for the students to attain the necessary information. Then, most of the students also suffered from the comprehension error in the Problem Number 3 and the transformation error in the Problem Number 5. On the other hand, the reading error was not found among the students. In general, the Grade V students had already possessed good reading skills.

The comprehension error might be traced back from the lack of the information that should be gathered as the basis in defining the problem-solving strategy in the subsequent stage. Approximately 113 students committed errors in understanding the Problem Number 3. The error percentage was 93.39\% and this error had been mostly committed by the students. The Problem Number 3 might be elaborated as follows: "Tika would like to go to the market. The distance between her house and the market is $1.25 \mathrm{~km}$. If Tika returns home directly through the same way, then how far is the distance that she has to travel?"

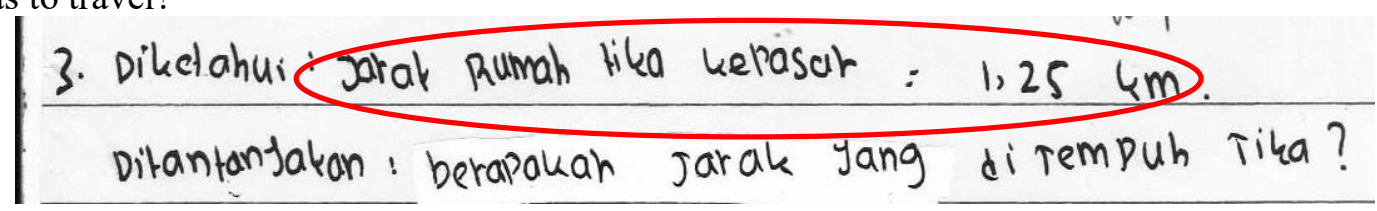

Figure 2. Comprehension Error

$\begin{aligned} \text { Jawab } & =\frac{13}{4} \times 5^{13}=000 \\ & =\frac{164000}{1}=160.000 x\end{aligned}$

Figure 3. Transformation Error 


$$
\text { Jawab: } 52.000: \frac{13}{4}=\frac{52}{100}: \frac{13}{4}: \frac{\frac{4}{2}}{100} \times \frac{89}{25}=\frac{167}{100}=\frac{4}{25}=29.000
$$

Figure 4. Process-Skill Error

The students were less careful in gathering the information about the distance between the market and Tika's house since the route was the same (Figure 2). Instead, the students only gathered the information that the distance that Tika should travel had been $1.25 \mathrm{~km}$ without notifying that the distance between the market and Tika's house had been the same; as a result, the distance should be multiplied by 2 or the distance to the market should be added by the distance to Tika's house. It should be that "The distance to the market $=$ The distance to Tika's house $=1.25 \mathrm{~km}$." The reason behind such error was that the students did not pay attention to the keyword in the narration of the test item namely "... through the same way ...."

Then, the subsequent type of error that had been committed was the transformation error. Transformation refers to the students' skills in formulating the problem-solving strategy by using the mathematical model. With reference to the statement, 98 students had committed the transformation error in the Problem Number 5 with the error percentage 80.99\%. The Problem Number 5 is as follows: "Indah bought $3 \frac{1}{4} \mathrm{kgs}$ of orange with the price IDR 52,000.00. How much is the price for a single $\mathrm{kg}$ of orange?"

In the case of transformation error, most of the students formulated the inappropriate equation. The students had been caught in the narration of the test item that prioritizes the divisor. As a result, the students arrived at the wrong answer. In Figure 3, the correct equation should be $52000 \div 3 \frac{1}{4}$. Not to mention, in Fraction the division model should be completed by using the reciprocal concept; as a consequence, although the students put the numerator and the denominator in the wrong position, a fraction that was easy to solve would still be generated without knowing whether the fraction was correct or incorrect.

Furthermore, the next type of error was the process-skill error. The process-skill error might be traced back into the answers that the students had elaborated in the answer-discovering process. In relation to this case, 100 students had committed this type of error in the Problem Number 5 with the error percentage $82.64 \%$.

In Figure 4, the formulation of the mathematical equation had been correct but, unfortunately, the calculation process had been incorrect and, therefore, the answer had been incorrect as well. In this regard, the transformation error might be overcome; however, there was another error that had been committed namely the process-skill error. An example of the process-skill error might be consulted in the Problem Number 6 with the error percentage 58.68\%. In the Problem Number 6, the students had difficulties in formulating the correct answer-discovering process (Figure 5). One of the factors behind such difficulty was found in calculation. The Problem Number 6 might be elaborated as follows: "Everyday Sari Gandum Bread Factory needs 2.35 quintals of wheat flour. How much wheat flour does the bready factory need in one month?"

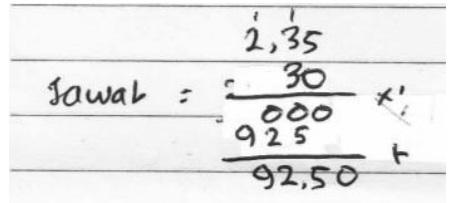

Figure 5. Process Skill Error

lawab: $\frac{8}{9}: \frac{1}{9}=\frac{\theta^{\prime}}{g_{i}} \times \frac{g^{\prime}}{1}=\frac{8}{1}=8$.
Jadi anak yang akan mendapat. kue dari pak rudi adalah 8 potong kur

Figure 6. Encoding Error 
Jurnal Prima Edukasia, 8 (1), 2020 - 36

Dwi Widyastuti Nurharyanto, Heri Retnawati

$\begin{aligned} & \text { Jawab }=\frac{13}{4} \times 5^{13}=000 \\ &=\frac{169000}{1}=160.000 \times \\ & \text { Jadi harga per } \mathrm{ka} \text { wah Jeruk adalah } 169.000\end{aligned}$

Figure 7. Encoding Error

In this case, the students implemented the compound multiplication as part of their problemsolving strategy. However, in the calculation process of the second stage the students had committed the calculation error. The number that should be generated from the multiplication was 705 instead of 925 . This error led the students to another error in the answer discovery.

The final type of error that the students had committed was the encoding error. The occurrence of the encoding error highly depended on the occurrence of the errors in the previous stages. If the students had made errors in understanding, transforming, and even calculating the test item then the students would have arrived at the wrong answer. Then, the encoding error had been committed by 55 students in the Problem Number 5 with the percentage 73.55\%. The encoding error embarked from the transformation error (Figure 3) which led the students to the incorrect answer (Figure 6) despite the correct calculation process. The transformation should embark from the correct mathematical form (this case has been explained in the transformation error within Figure 3) and proceed to the calculation process stage with the following answer discovery: $52000 \div 3 \frac{1}{4}=52000 \times \frac{4}{13}=16000$.

In addition to the Problem Number 5, the students also committed error in the Problem Number 4 with the answer discovery that had been elaborated in Figure 7. The Problem Number 4 might be elaborated as follows: "Mr. Rudi has $\frac{8}{9}$ cake. The cake will be divided into each of his child under the same portion namely $\frac{1}{9}$. How many children should Mr. Rudi distribute the cake to?" In the Problem Number 4, the understanding, the transformation, and the process-skill stage might be completed by the students well. Unfortunately, the students wrote the incorrect attribute when they arrived at the final answer. The answer should 8 children instead of 8 pieces of cake.

\section{Discussions}

The students' difficulties in solving the narrative-type test item might be traced back from the errors that the students have committed. In relation to the statement, most of the students have committed the reading error toward the context of the test item. In this regard, the students gather the unnecessary instead of the necessary information. Indeed, the students have been able to read the narration in the test item well but they are unable to attain the information that becomes the key to the problem-solving initiative. This situation becomes the reason why the students have committed errors in the subsequent stages. These findings are in accordance to the results of the study by Daroczy et al. (2015, p. 5), which state that students' understanding is an important key in completing the test items. In the mathematical narration, many vocabularies are implicit; for example, the operation of summation is symbolized by the phrase "the total amount that one has" or "given by." The results of a study by Boonen et al. (2016, p. 7) show that the highest concern in Mathematics is the students' courage to complete the test item with the abandonment of their semantic skills.

Semantic skills are the basis of the comprehension skills. these skills are necessary for the students in attaining the important information. The important information, later, will serve as the basis for formulating the mathematical model of the given problems. Certainly, this sequence will proceed to the subsequent stages namely the calculation process and the final answer discovery.

Semantic skills refer to the skills that the students utilize in understanding or comprehending the meaning of either a word or a sentence. The understanding toward semantic skills becomes important and necessary in order to attain important information within the strategy formulation (Zhou et al., 2018, p. 368). In relation to the statement, according to Retnawati and Wulandari $(2019$, p. 551), the provision of narrative-type test item to the students might improve their literacy skills. 
Another factor that becomes the obstacle in completing the narrative-type test item is the students' transformation skills. The students suffer from the difficulties in modelling the narration into the formal mathematical equation (Sumule et al., 2018, p. 6). This statement is also supported by (Ahyan et al., 2019 , p. 4), who state that there are a number of factors that lie behind the students' transformation error namely: (1) being highly habituated to the procedural skills; (2) being too influenced by the test item context; (3) being exposed to the incorrect mathematical concept; and (4) being too influenced by the figures or the graphics that have been displayed in the test item. The more seldom the students complete the narrative-type test item, the easier the students will be influenced by these factors.

In addition to the transformation error, the process-skills error becomes the second highest difficulty. The process-skills error has been influenced by the students' calculation skills. The students who are less accurate and who tend to be hesitant gain the incorrect calculation results despite the fact that their model of mathematical transformation has been correct. At the same time, the process-skills error has also been influenced by the students' ignorance in implementing the correct strategy for solving the calculation opertion in the fraction (Lestiana et al., 2017, p. 138). Certain strategies in the fraction operation might be implemented when the students have both understood and even learned the operation.

Another factor that also contributes to the occurence of the process-skills error is the materials that have been delivered. Learning materials of Fraction might have been confusing for the students. The students are possibly able to transform the narrative-type test item into the mathematical model; however, the students might ignore that fraction has denominator and, consequently, they should pay attention to the denominator in performing the calculation operation. Aksoy and Yazlik (2017, p. 231) state that understanding how the calculation operation should be performed in Fraction has been a difficult part in the learning process. The errors in the calculation process will certaily lead to the errors in discovering the final answer.

In order to overcome the difficulties within the completion of the narrative-type test items, there are several ways that might be afforded. As having been suggested by Hirashima et al. (2015, p. 9); Khodeir et al. (2017, p. 204); and also Walkington et al. (2015), several innovations should be introduced. One of such innovations might be ranging from the use media that are compatible to the context of the narrative-type test item until the combined use of the computer in solving the problems in the narrative-type test item. However, the completion of the narrative-type test item depends on the students' problem-solving skills. The students' problem-solving skills might be improved by using the Android system that has been functioned to solve mathematical problems (Damayanti \& Mawardi, 2018, p. 1). Furthermore, the use of comic or textbook as learning media is also able to facilitate the students in the learning process of Mathematics (Suryatin \& Sugiman, 2019, p. 58). Habituating the students with the narration that has been associated to the students' daily life will certainly facilitate the students in completing the narrative-type test item or any test item that has quite time-consuming narration. On the other hand, the teachers are expected to improve the learning process quality by paying attention to the difficulties that the students have. The reason is that the students' difficulties lead them to be highly concerned in completing the test item and the situation might even be worse when the students have a mindset that Mathematics is a terrifying lesson (Ahmad, 2016, p. 261). However, the facts in the field show that the teachers have delivered the learning materials based on the lesson plans without viewing or analysing the students' difficulties first (Wijaya et al., 2019, p. 357). This is the reason why the learning process in the future should be improved. One of the improvements that might be pursued is running a diagnostic test so that the teachers might identify the students' weaknesses.

Diagnostic test becomes important because through the use of the diagnostic test the learning process might be easier to direct in order that the students' difficulties might be studied in-depth. With reference to the statement, the time allocation in running the diagnostic test should be efficient as well. Eventually, by running the diagnostic test the techers will be able to identify which materials that should be taught briefly and which materials that should be provided with in-depth understanding.

\section{Conclusions}

The error that most of the students generally commit is the comprehension error. The comprehension skills serve as the preliminary step for the students in attainng the important information, which will be manifested into the mathematical model. Therefore, the students' comprehension skills become important because Mathematics does not only demand good calculation skills but also good 
semantic skills. In order to overcome this gap, the part that should be emphasized in the learning process is the students' semantic skills or how the students understand the meaning of a word in its relation with a single sentence relative to the context of the sentence. Furthermore, in addition to generally committing the comprehension error, the students also commit the transformation eror, the process-skills error, and the encoding error.

The numerous students' errors that have been analysed represent the difficulties that they experience in completing the narrative-type test item. In order to overcome these difficulties, as the authority in the classroom the teachers might combine the Mathematics learning process and the use of interesting learning media. Certainly, in this combination the most important part is that the students' problem-solving skills should be improved.

Departing from the results of the study, it might be suggested that the students' semantic skills should be reinforced. The reason is that Mathematics does not only require the calculation skills but also the good linguistic skills. Then, in order to maximize the learning process, the teachers might run the diagnostic test first in order to identify the students' difficulties. The results of the diagnostic test, later, might serve as the guidelines for implementing the appropriate strategy in the learning process.

\section{References}

Abdullah, A. H., Abidin, N. L. Z., \& Ali, M. (2015). Analysis of students' errors in solving higher order thinking skills (HOTS) problems for the topic of fraction. Asian Social Science, 11(21), 133-142. https://doi.org/10.5539/ass.v11n21p133

Ahmad, S. R. S. (2016). Pengaruh math phobia, self-efficacy, adversity quotient dan motivasi berprestasi terhadap prestasi belajar matematika siswa SMP. Jurnal Riset Pendidikan Matematika, 3(2), 259272. https://doi.org/10.21831/jrpm.v3i2.6138

Ahyan, S., Turmudi, \& Prabawanto, S. (2019). Students' Errors in solving the PISA mathematics problem using Newman's error categories. Journal of Physics: Conference Series, 1363(1), 012088. https://doi.org/10.1088/1742-6596/1363/1/012088

Aksoy, N. C., \& Yazlik, D. O. (2017). Student errors in fractions and possible causes of these errors. Journal of Education and Training Studies, 5(11), 219. https://doi.org/10.11114/jets.v5i11.2679

Arfiana, A., \& Wijaya, A. (2018). Problem solving skill of students of senior high schools and Islamic high schools in Tegal Regency in solving the problem of PISA based on Polya's stage. Jurnal Riset Pendidikan Matematika, 5(2), 211-222. https://doi.org/10.21831/jrpm.v5i2.15783

Boonen, A. J. H., de Koning, B. B., Jolles, J., \& van der Schoot, M. (2016). Word problem solving in contemporary math education: A plea for reading comprehension skills training. Frontiers in Psychology, 7(February), 1-10. https://doi.org/10.3389/fpsyg.2016.00191

Charlesworth, R., \& Lind, K. K. (2010). Math \& science: For young children (6th ed.). Wadsworth Cengange Learning.

Damayanti, R., \& Mawardi, M. (2018). Developing of MITRA learning model of problem solving-based to solve mathematical problems in elementary school. Jurnal Prima Edukasia, 6(1), 1. https://doi.org/10.21831/jpe.v6i1.17238

Daroczy, G., Wolska, M., Meurers, W. D., \& Nuerk, H. C. (2015). Word problems: A review of linguistic and numerical factors contributing to their difficulty. Frontiers in Psychology, 6, 1-13. https://doi.org/10.3389/fpsyg.2015.00348

Große, C. S. (2014). Learning to solve story problems-supporting transitions between reality and mathematics. European Journal of Psychology of Education, 29(4), 619-634. https://doi.org/10.1007/s10212-014-0217-6

Hadi, S., Retnawati, H., Munadi, S., Apino, E., \& Wulandari, N. F. (2018). The difficulties of high school students in solvsing higher-order thinking skills problems. Problems of Education in the 21st Century, 76(4), 520-532.

Hirashima, T., Hayashi, Y., Yamamoto, S., \& Kazushige, M. (2015). Bridging model between problem and solution representations in arithmetic/mathematics word problems. Proceedings of the $23 \mathrm{rd}$ International Conference on Computers in Education, ICCE 2015, 9-18.

Jiang, C. (2013). Errors in solving word problems on speed: a case in singapore and mainland china. 
12th International Congress on Mathematical Education, 16(1), 56-75.

Khodeir, N., Wanas, N., Elazhary, H., \& Hegazy, N. (2017). Addressing student misinterpretations of story problems in MAST. ACCS/PEIT 2017 - 2017 Intl Conf on Advanced Control Circuits Systems and 2017 Intl Conf on New Paradigms in Electronics and Information Technology, 204211. https://doi.org/10.1109/ACCS-PEIT.2017.8303042

Lestiana, H. T., Rejeki, S., \& Setyawan, F. (2017). Identifying students' errors on fractions. JRAMathEdu (Journal of Research and Advances in Mathematics Education), 1(2), 131-139. https://doi.org/10.23917/jramathedu.v1i2.3396

Newton, N. (2017). Math problem solving in action. In Math Problem Solving in Action. Routledge. https://doi.org/10.4324/9781315465050

Prakitipong, N., \& Nakamura, S. (2006). Analysis of mathematics performance of grade five students in Thailand using Newman procedure. Journal of International Cooperation in Education, 9(1), 111-122. https://home.hiroshima-u.ac.jp/cice/wp-content/uploads/2014/03/9-1-9.pdf

Pugalee, D. K. (2001). Writing, mathematics, and metacognition: Looking for connections through students' work in mathematical problem solving. School Science and Mathematics, 101(5), 236245. https://doi.org/10.1111/j.1949-8594.2001.tb18026.x

Rahmawati, F., \& Retnawati, H. (2019). An analysis of students' difficulties in solving PISA-like mathematical problems. Journal of Physics: Conference Series, 1200(1), 012015. https://doi.org/10.1088/1742-6596/1200/1/012015

Retnawati, H. (2017). Diagnosing the junior high school student's difficulties in learning mathematics. International Journal on New Trends in Education and Their Implications, 8(1), 33-50.

Retnawati, H., \& Wulandari, N. F. (2019). The development of students' understanding of science. Frontiers in Education, 4(4), 502-514. https://doi.org/10.3389/feduc.2019.00032

Sumantri, M. S., \& Satriani, R. (2016). The effect of formative testing and self-directed learning on mathematics learning outcomes. International Electronic Journal of Elementary Education, 8(3), 507-524. https://iejee.com/index.php/IEJEE/article/view/128

Sumule, U., Amin, S. M., \& Fuad, Y. (2018). Error analysis of indonesian junior high school student in solving space and shape content PISA problem using newman procedure. Journal of Physics: Conference Series, 947(1), 012053. https://doi.org/10.1088/1742-6596/947/1/012053

Suryatin, S., \& Sugiman, S. (2019). Comic book for improving the elementary school students' mathematical problem solving skills and self-confidence. Jurnal Prima Edukasia, 7(1), 58-72. https://doi.org/10.21831/jpe.v7i1.10747

Tong, D. H., \& Loc, N. P. (2017). Students' errors in solving mathematical word problems and their ability in identifying errors in wrong solutions. European Journal of Education Studies, 3(6), 226-241. https://doi.org/10.5281/zenodo.581482

Ulu, M. (2017). Errors made by elementary fourth grade students when modelling word problems and the elimination of those errors through scaffolding. International Electronic Journal of Elementary Education, 9(3), 553-580. https://iejee.com/index.php/IEJEE/article/view/176

Walkington, C., Clinton, V., Ritter, S. N., \& Nathan, M. J. (2015). How readability and topic incidence relate to performance on mathematics story problems in computer-based curricula. Journal of Educational Psychology, 107(4), 1051-1074. https://doi.org/10.1037/edu0000036

Wijaya, A., Retnawati, H., Setyaningrum, W., Aoyama, K., \& Sugiman. (2019). Diagnosing students' learning difficulties in the eyes of Indonesian mathematics teachers. Journal on Mathematics Education, 10(3), 357-364. https://doi.org/10.22342/jme.10.3.7798.357-364

Wijaya, A., van den Heuvel-Panhuizen, M., Doorman, M., \& Robitzsch, A. (2014). Difficulties in solving context-based PISA mathematics tasks: An analysis of students' errors. The Mathematics Enthusiast, 11(3). http://scholarworks.umt.edu/tme/vol11/iss3/8

Zhou, X., Li, M., Li, L., Zhang, Y., Cui, J., Liu, J., \& Chen, C. (2018). The semantic system is involved in mathematical problem solving. NeuroImage, 166, 360-370. https://doi.org/10.1016/j.neuroimage.2017.11.017 